\title{
Nutrition as a Tool to Control Periodontal Diseases in Dogs and Cats
}

\author{
Patrícia Massae Oba, Mariana Fragoso Rentas, Thiago Henrique Vendramini and Marcio Antonio Brunetto* \\ School of Veterinary Medicine and Animal Science, University of São Paulo (USP), Brazil
}

Submission: December 14, 2017; Published: January 12, 2018

*Corresponding author: Marcio Antonio Brunetto, School of Veterinary Medicine and Animal Science, University of São Paulo (USP), Brazil, Tel: +55 193565 4226; Email: mabrunetto@usp.br

\begin{abstract}
The relationship between food and alteration in oral health has been studied. Whether the mechanical effect of the food on the bacterial plaque, the use of additives to control the plaque calcification or even supplements capable of modulating the oral micro biota, all these techniques have already been tested to maintain or improve the oral health in pets. It is well established that soft foods are associated with increased frequency and severity of periodontal diseases, and that harder diets promote a mechanical removal of bacterial plaque. The phosphate salts have anti-calculus forming properties, and it has been used by the pet food industry for years. Igy-GP blocks the effect of gingipain and improves the oral health of cats and dogs. Omega- 3 can be an allele in controlling the inflammation caused by periodontal disease.
\end{abstract}

Keywords: Oral health; Supplement; Diet

\section{Introduction}

Affecting more than $60 \%$ of the adult companion animal population, periodontal disease is associated with pain, halitosis, mucosal ulceration and loss alveolar bones and teeth, being progressive with age and more frequently affecting animals fed with wet diets [1-4]. Many commercial treats aimed at improving the oral health of pets by the use of mechanical scraping to clean the teeth by changes in texture and size of kibbles. This mechanical effect disaggregates the plaque and calculus from the tooth surface while the animal chews, but this benefit is only accomplished on the teeth that are used during chewing [5,6]. Another approach is to coat kibbles or snacks with phosphate salts, such as sodium polyphosphate or hexametaphosphate. These additives reduce dental plaque mineralization by it chelating effect on the salivary calcium, avoiding it deposition over the teeth [7-12]. Immunoglobulin $\mathrm{Y}$ against gingipain (IgY-GP) has emerged as promising alternatives to promote oral health. Blocking the effect of gingipain this additive prevents the formation of periodontal pocket and consequently the progression of periodontal disease. Positive results with the use of IgY-GP in the oral health of dogs and cats have been reported, reducing dental plaque in cats and dental calculus and gingivitis in dogs $[13,14]$. Omega-3 can control the production of inflammatory compounds aiding in cases where periodontal disease already causes inflammation and pain [15]. Xylitol may help improve oral health in pets, with interesting results in cats where its use has reduced the plaque and calculus accumulation [16].

\section{Discussion}

It is already well established that diet management and home oral hygiene are important factors that influence oral health in dogs and cats [3,5, 9,17-21]. Feeding dogs and cat with dry food diet has a positive influence on oral health, decreasing the occurrence of mandibular lymphadenopathy, dental deposits and periodontal diseases in comparison with mixed food (dry and soft food) and soft food [3]. Another study found that home-prepared diet increased the probability of an oral health problem in both cats and dogs [20]. Looking at the side of kibble size, increasing kibble diameter by $50 \%$ was associated with a $42 \%$ calculus reduction in dogs [9].

The use of chewing items to reduce dental calculus is very common practice. Dogs that received one dental chew each day had a statistically significant reduction in plaque and calculus accumulation, and oral malodor [21]. Another study reported that the use of daily oral hygiene chews reduced in $17.3 \%$ plaque deposition and $45.8 \%$ calculus accumulation in small breed dogs [6]. For cats, the use of daily dental chews was effective in reducing plaque and calculus accumulation on tooth surfaces, as well as reducing the severity of gingivitis $[5,22]$. 
One of the most used supplements to control periodontal disease in the pet food industry is phosphate salts, among them the sodium polyphosphate or hexametaphosphate. The phosphate salts are a sequestrant that binds salivary calcium making it less available for precipitation as dental calculus $[7,8]$. Normally, these salts are added to the surface of dental treats or dental diet and it promotes a significant reduction on the calculus accumulation in studies with dogs [7-12]. Coating the kibbles with sodium tripolyphosphate induced a 55\% calculus reduction in dogs [9].

Although polyphosphates control plaque calcification, it does not prevent the proliferation of pathogenic bacteria. In this sense, the use of anti-gingipain IgY (IgY-GP) has emerged as a promising alternative to conventional prevention and treatment methods. By blocking the effect of gingipains it avoids the disruption of cell adhesion and therefore, prevent the formation of periodontal pocket and consequently the progression of periodontal disease [23,24]. In cats, the consumption this additive on the diet coat $(4 \mathrm{~g} / \mathrm{kg}$ of diet) was able to reduce dental plaque [14]. In dogs, $35 \mathrm{mg} / \mathrm{kg}$ of body weight once a day and $17.5 \mathrm{mg} / \mathrm{kg}$ of body weight twice a day reduced significantly the dental calculus and gingivitis [13].

Another supplement that has been studied to improve oral health is the omega-3. The argument for the use of omega- 3 it that this additive is capable of decreases the production of proinflammatory cytokines [25]. Diets with the 10:1 ratio (omega6:omega-3) lowered pro-inflammatory cytokines compared to the diet with the 40:1 ratio in cats with chronic gingivitis/ stomatitis [15], but more studies in this species as well in dogs are necessary. Another additive that needs more studies is thexylitol, with has been shown to have an antibacterial effect on oral bacteria and dental plaque, as well as anti-calculus forming properties [26-29]. Adding xylitol to the water of cats resulted in the reduction of plaque and calculus accumulations [16].

\section{Conclusion}

Based on the evidence presented, information currently available suggests that diet can control and improve the oral health of dogs and cats. Being the most used by the pet food industry the mechanical effect along with the use of polyphosphate salts. Though, the use of IgY-GP, omega-3, and xylitol can potentially be used in the pet food market. However, more studies are needed to define the best dose and vehicle to promote its best effect on controlling and preventing the periodontal disease.

\section{References}

1. Lommer MJ,Verstraete FJ (2001) Radiographic patterns of periodontitis in cats: 147 cases (1998-1999). J Am Vet Med Assoc 218(2): 230-234.

2. Harvey CE (2005) Management of periodontal disease: understanding the options. Vet Clin North Am Small Anim Pract 35(4): 819-836.
3. Gawor JP, Reiter AM, Jodkowska K, Kurski G, Wojtacki MP, et al. (2006) Influence of diet on oral health in cats and dogs. J Nutr 136(7 Suppl): 2021S-2023S

4. Southerden P (2010) Review of feline oral disease. In practice 32(2): 51-56.

5. Ingham KE, Gorrel C, Bierer TL (2002) Effect of a dental chew on dental substrates and gingivitis in cats. J Vet Dent. 19(4): 201-204.

6. Hennet P, Servet E, Venet C (2006) Effectiveness of an oral hygiene chew to reduce dental deposits in small breed dogs. J Vet Dent 23(1): 6-12.

7. Stookey GK, Warrick JM, Miller LL, Katz BP (1996) Hexametaphosphatecoated snack biscuits significantly reduce calculus formation in dogs. Journal of veterinary dentistry 13(1): 27-30.

8. White DJ, Gerlach RW (2000) Anticalculus effects of a novel, dualphase polypyrophosphate dentifrice: chemical basis, mechanism, and clinical response. J Contemp Dent Pract 1(4): 1-12.

9. Hennet P, Servet E, Soulard Y, Biourge V (2007) Effect of pellet food size and polyphosphates in preventing calculus accumulation in dogs. J Vet Dent 24(4): 236-239.

10. Paiva AC, Saad FMOB, Leite CAL, Duarte A, Pereira DAR, et al. (2007) Eficácia dos coadjuvantes de higiene bucal utilizados na alimentação de cães. Arq Bras Med. Vet Zootec 59(5): 1177-1183.

11. Carciofi AC, Bazolli RS, Barbudo GR, Zanni A, Carvalho AZ (2008) Efeito de biscoito extrusado com cobertura de pirofosfato de sódio sobre o cálculo e a placa dentária pré-existentes em cães. ArsVeterinaria 23(1): 47-53.

12. Pinto ABF, Saad FMOB, Leite CAL, Aquino AA, Alves MP, et al. (2008) Sodium tripolyphosphate and sodium hexametaphosphate in preventing dental calculus accumulation in dogs. Arq Bras Med Vet Zootec 60(6): 1426-1431.

13. Shofiqur RA, Ibrahim ESM, Isoda R, Umeda K, Nguyen VS, et al. (2011) Effect of passive immunization by anti-gingipainIgY on periodontal health of dogs. Veterinary science development 1(1): 8.

14. Oba PM, Devito FC, Santos JPF, Stipp RN, Gomes MOS, et al. Effects of passive immunization by anti-gingipainIgY on the oral health of cats fed with kibble diets. Journal of veterinary dentistry (in press).

15. Corbee RJ, Booij-Vrieling HE, van de Lest CH, Penning LC, Tryfonidou MA, et al. (2012) Inflammation and wound healing in cats with chronic gingivitis/stomatitis after extraction of all premolars and molars were not affected by feeding of two diets with different omega-6/omega-3 polyunsaturated fatty acid ratios. J Anim Physiol Anim Nutr (Berl) 96(4): 671-680.

16. Clarke DE (2006) Drinking water additive decreases plaque and calculus accumulation in cats. J Vet Dent 23(2): 79-82.

17. Logan EI, Finney O, Hefferren JJ (2002) Effects of a dental food on plaque accumulation and gingival health in dogs. J Vet Dent 19(1): 1518.

18. Thyse LFH, Vrieling HE, Dijkshoorn NA, Picavet P, Logan EI (2003) Hill's Prescription Diet Feline t/d: results of a field study. In: Proceedings of the Hill's european symposium on oral care, p. 19-21.

19. Logan EI (2006) Dietary influences on periodontal health in dogs and cats. Vet Clin North Am Small Anim Pract 36(6): 1385-1401.

20. Buckley C, Colyer A, Skrzywanek M, Jodkowska K, Kurski G, et al. (2011) The impact of home-prepared diets and home oral hygiene on oral health in cats and dogs. Br J Nutr 106(Suppl 1), S124-S127.

21. Quest BW (2013) Oral health benefits of a daily dental chew in dogs. J Vet Dent 30(2): 84-87. 
22. Gorrel C (1998) Periodontal disease and diet in domestic pets. JNutr 128(12 Suppl): 2712S-2714S.

23. Imamura $\mathrm{T}$ (2003) The role of gingipains in the pathogenesis of periodontal disease. J Periodontol 74(1): 111-118.

24. Yokoyama K, Sugano N, Shimada T, Shofiqur RA, Ibrahim el-SM, et al. (2007) Effects of egg yolk antibody against Porphyromonas gingivalis gingipains in periodontitis patients. J Oral Sci 49(3): 201-206.

25. Rosenstein ED, Kushner LJ, Kramer N, Kazandjian G (2003) Pilot study of dietary fatty acid supplementation in the treatment of adult periodontitis. Prostaglandins, leukotrienes and essential fatty acids 68(3): 213-218
26. Wåler SM, Rölla G, Assev S, Ciardi JE (1984) The effect of xylitol on plaque metabolism. Swed Dent J 8(3): 155-161.

27. Trahan L (1995) Xylitol: a review of its action on mutans streptococci and dental plaque--its clinical significance. Int Dent J 45(1 Suppl 1): 77-92.

28. Stookey GK, Warrick JM, Miller LL (1995) Effect of sodium hexameta phosphate on dental calculus formation in dogs. Am J Vet Res 56(7): 913-918.

29. Warrick JM, Stookey GK (2004) Overview of clinical trials using sodium hexametaphosphate for prevention of dental calculus. In: Proceedings of veterinary dentistry forum 18: 272-276.

\section{Your next submission with Juniper Publishers will reach you the below assets}

- Quality Editorial service

- Swift Peer Review

- Reprints availability

- E-prints Service

- Manuscript Podcast for convenient understanding

- Global attainment for your research

- Manuscript accessibility in different formats ( Pdf, E-pub, Full Text, Audio)

- Unceasing customer service

Track the below URL for one-step submission https://juniperpublishers.com/online-submission.php 